\title{
Semiotician or hermeneutician? Jakob von Uexküll revisited
}

\author{
Han-liang Chang \\ National Taiwan University \\ No. 1, Sec. 4, Roosevelt Road, Taipei, 106 Taiwan \\ e-mail: changhl@ccms.ntu.edu.tw
}

\begin{abstract}
Like other sciences, biosemiotics also has its time-honoured archive, consisting, among other things, of writings by those who have been invented and revered as ancestors of the discipline. One such example is Jakob von Uexküll who has been hailed as a precursor of semiotics, developing his theory of "sign" and "meaning" independently of Saussure and Peirce. The juxtaposition of "sign" and "meaning" is revelatory because one can equally legitimately claim Uexküll as a hermeneutician in the same way as others having claimed him as a semiotician. Such a novel temptation can be justified by Uexküll's prolonged obsession with Sinn and Bedeutung since his first book in 1909. This paper attempts to reconstruct the immediate intellectual horizon of Uexküll's historicity, a discursive space traversed by his contemporaries Frege and Husserl, in order to see how Uexküll's discussions of Zeichen and Gegenstand, Sinn and Bedeutung, were informed by other philosophers of language, and to establish Uexküll as a phenomenological hermeneutician in the tradition of Husserl, Heidegger and Gadamer. To forestall and counter possible criticism that hermeneutics is primarily concerned with textual interpretation, while Uexküll is at most an interpreter of animal life, the paper will discuss his unfinished parody of the Platonic dialogue Meno, which is entitled Die ewige Frage: Biologische Variationen über einen platonischen Dialog (1943). It is through such textual practice that one witnesses the emergence of an Uexküll who embodies at once the addressee exercising his understanding of ancient texts as well as the second addresser recoding his explanation to another group of targeted addressees. This textual practice already goes beyond the confines of biology and in fact involves the linguistic pragmatics of rhetoric and speech act.
\end{abstract}




\section{Han-liang Chang}

Like other sciences, biosemiotics also has its time-honoured archive, consisting, among other things, of writings by those who have been invented and revered as ancestors of the discipline. One such example is Jakob von Uexküll. As to the people who "invent" him, they are either mediators of semiotic globalisation, like the late Professor Thomas A. Sebeok, or de facto progenitor like Professor Thure von Uexküll. Since Sebeok's seminal promulgation in Semiotica and his enthusiastic promotion, the legacy of Uexküll as another precursor of semiotics, who had worked independently of Charles Sanders Peirce and Ferdinand de Saussure, has become generally known to us. What is not known to us, as is the reality of human knowledge, is the fact that other people, each from her persuasion, and in her own way, may also legitimately claim Jakob von Uexküll. This not only shows the wide scope of Jakob's knowledge, but also raises the thorny issue of conflict in interpretations. What I have in mind is hermeneutics, whose primary concern is the processing of meaning.

However, one does not invent her ancestor randomly because she is always already situated in her disciplinary tradition and can make claim only from within that context. Therefore, it is quite natural for a historian of biology like Erik Nordenskiöld to label Uexküll as a vitalist; Ernst Cassirer to stick to him the sobriquet of Neo-Kantian; Hans-Georg Gadamer to summon him to the camp of fellow phenomenologists; and Sebeok to honour him as a founder of semiotics. Much as a biosemiotician claims Uexküll, a biohermeneutician like Sergey V. Chebanov can lay equally legitimate claim.

To label Uexküll as a hermeneutician, rather than the more accepted semiotician, is no easy task. There are several difficulties confronting us, but let me point out just two. First, hermeneutics deals with the theory and method of understanding, traditionally of text, and through the latter, the thought behind it or prior to it. Therefore, it involves the proper decipherment of meaning, supposedly emitted from a source, and thus presupposes continuity between addresser, encoded message, and addressee. The procedure of decipherment for what is behind the sign is quite different from the heuristics of semiotics, which is more concerned with system-specific functionality of sign, e.g., how does the sign process rather than what it means. ${ }^{1}$ Second, Uexküll deals, though not exclusively,

It is no accident that I have evoked Paul Ricoeur. The French philosopher contrasts two kinds of human understanding: one is immediate, non-programmatic, and subjective, or "Heideggerian" and "Husserlian"; the other is 
with the meaning of animal life rather than text. This categorial shift further raises the questions of validity in applying hermeneutics to nature, in textualising nature, and, above all, in begging the question of "meaning of meaning" to which the biologist addresses himself. Such questions are complicated by Uexküll's obsession with meaning, since his first book in 1909, where he observes "each newly discovered fact [...] gain[s] sense [Sinn] and significance [Bedeutung]" (Uexküll 1985: 224; Uexküll 1909: 7), all the way to Bedeutungslehre in $1940 .^{2}$

methodical and programmatic and claimingly objective. Ricoeur traces this distinction to Dilthey's distinction between understanding and explanation (in his words, "a German product") and interprets the two procedures as hermeneutics versus semiotics $(1974 ; 1990)$. Incidentally, Thure von Uexküll alludes to Dilthey's distinction (1987: 153): "If science is understood as the attempt to identify the factors which determine the behavior of phenomena in relation to each other and toward man, then Dilthey's famous distinction is no longer valid for a theory of signs. 'Explaining' (Erklären), which according to Dilthey is restricted to the natural sciences, becomes identical with 'understanding' (Verstehen), which he reserved for the human sciences."

Uexküll's semiotic project falls into the category of Ricoeurian explanation in his assumption that all animal perception, action, reaction [behaviours] in relation to the external world can be explained in terms of sign processing. The teleological nature of his Bauplan is also interpretative. It parallels the Kantian concept of purposiveness of nature (Zweck, Zweckmässig), which "represents the unique way in which we must proceed in reflection on the object of nature with the aim of a thoroughly interconnected experience, consequently it is a subjective principle (maxim) of the power of judgment" (Kant 2000: 71).

While Manfred D. Laubichler alternates between biosemiotics and biohermeneutics (Laubichler 1997a; 1997b), obviously finding it difficult to reconcile interpretation and description of operational processes, Sergey V. Chebanov (1993) provides a better hermeneutic model of interpretation processes (IP) in biology and life based on linguistic pragmatics. He prefers the discipline of hermeneutics to semiotics in interpreting, for instance, the interactions of sensible beings and living beings, called enlogue or quasi-dialogue (Chebanov 1993: 225). More importantly, he believes biosemiotics is a division of biohermeneutics: "Now, while the hermeneutization of humanitarian disciplines is being developed and some domains of biosemiotics appear to be involved in it, I find sufficient reasons to call this trend "biohermeneutics"' (Chebanov 1993: 40).

2 In one of his first published book in 1909, Jakob von Uexküll had already used the two terms Sinn and Bedeutung together, reminding one of Frege's classic distinction. "If the organization of the construction plan is placed at the focus of research for every species, then each newly discovered fact finds its natural place, and only thus does it gain sense and significance" (Uexküll 1985: 224) ("Wird die Ausgestaltung des Bauplanes für jede Tierart in den Mittelpunkt der Forschung 
Our hermeneutic task is then two-fold: on the one hand, we need to reconstruct the conceptual and semantic horizon in which Uexküll's usage of meaning and sign is embedded, and on the other, to carve out of his less read writings an image of textual hermeneutician. Regarding the latter less known aspect of Uexküll, I refer, in particular, to his unfinished parody of the Platonic dialogue Meno, which is entitled "Die ewige Frage: Biologische Variationen über einen platonischen Dialog" (1943). It is through such textual practice that one witnesses the emergence of an Uexküll who embodies at once the addressee exercising his understanding of ancient texts as well as the second addresser recoding his explanation to another group of targeted contemporary German addressees. This textual practice already goes beyond the confines of biology and in fact involves the linguistic pragmatics of rhetoric and speech act.

As I have pointed out, it is due to Thomas A. Sebeok's unfailing effort of promotion that Jakob von Uexküll as a forerunner of semiotics has been accepted and rarely questioned. Although Uexküll developed his theory of sign and meaning independently of Saussure and Peirce, quite a few scholars have attempted to negotiate him with these two founders of sémiologie and semeiotic. One of the attempts is to draw an analogy between biology and linguistics, using, as model, the dual structure of sign consisting of signifiant and signifié, and projecting it onto biological phenomena. In this regard, the most notable example is none other than Thure von Uexküll. Since the linguistic model has been challenged from time to time and even made obsolete among certain poststructuralist camps, a few attempts to appropriate Peirce have been made, especially the version to establish the Peircian link to biology.

Since human thinking is essentially model-bound, whether or not the Saussurian and Peircian applications are appropriate is a metatheoretical matter not concerned here, but I am afraid that such applications fail to do justice to Uexküll as a forerunner independent of Saussure and Peirce. Specifically, the more we think of Uexküll in light of the Latinate sign and the Greek semeion, the less can we appreciate Uexküll in light of his own conceptual context and the tradition to which he belongs. Before addressing myself to the main

gestellt, so findet jede neuentdeckte Tatsache ihre naturgemässe Stelle, an der sie erst Sinn erhält und Bedeutung") (Uexküll 1909: 7). 
issues, let me mention in passing the terminological problem. For instance, the German word Zeichen has been translated, without much reflection, into sign in the English version of Theoretical Biology (1926) and in the long essay, "Theory of Meaning", which constitutes the main body of the 1982 special issue of Semiotica. It is in the latter title that the English word meaning is used indiscriminately for the illdefined Bedeutung. This probably accurate but misleading translation has not been clarified, as it should have, not least for its unavoidable entanglement, following Gottlob Frege (1848-1925), with Sinn, and to a lesser degree, with Zeichen and Vorstellung. Likewise, a key word in Uexküll's system, Merk, which can refer to both mark and perceptual sign, as in Merkmal, has not received due attention by semioticians.

\section{Sinn or Bedeutung: The Frege-Husserl-Uexküll complex}

Anyone familiar with the philosophical context will have already detected the ghosts of Gottlob Frege and Edmund Husserl (18591938) haunting Uexküll's writings, maybe without his awareness. ${ }^{3}$ I am not suggesting influence, a vague concept — indeed a nonissue - that had unfortunately plagued many a comparatist in the 1960s-1970s. Instead of establishing points of contact showing positivistic rigour, we tend to bracket the issue and replace it with a more explanatory, albeit no less vague, intertextual space. A cliché runs like this: Embedded in her cultural Umwelt, a poet does not need to read a Petrarchan sonnet to write one. It is under a similar cultural milieu, which witnessed the birth and growth of a scientific discourse through the exchange, debates, and brainstorming of such great minds as Frege, Husserl, and Wilhelm Dilthey that Uexküll developed his theory of sign and meaning at the turn of the twentieth century.

\footnotetext{
3 Witness what the latter has to say: "Each general name is a sign for a general representation, and this, in turn, is a sign for any object that falls under the corresponding abstract concept [...]. Furthermore [...] we take any conceptual mark (Merkmal) - so far as it serves, precisely, as a distinguishing mark - to be a sign" ("Jeder allgemeine Name ist ein Zeichen für eine allgemeine Vorstellung, und diese wiederum ist ein Zeichen für jeden der Gegenstände, welche unterden korrespondierenden abstrakten Begriff fallen [...] Des weiteren gilt uns [...] jades begriffliche Merkmal, sofern es eben als Merkmal dient, als Zeichen") (in German, Husserl 1970: 340; in English, Husserl 1994: 20-21).
} 
In the following, I will situate Uexküll in his immediate discursive context by evoking his contemporaries and predecessors Frege and Husserl. It is generally agreed that Uexküll's major contribution to theoretical biology and semiotics lies in his theory of meaning, that is, theory of meaning in life, which can be called, as with his titles Bedeutungslehre (1940) and Der Sinn des Lebens (1947); it also lies in his reinstatement of the idealistic, subjective paradigm of biology. Now it is due to Frege's renowned "puzzle" on the distinction between Sinn and Bedeutung that modern theory of meaning, in particular logical semantics, has come into being. And Husserl's discussion of the subjective lived experience (Erlebnis) has given rise to the rich phenomenological tradition that includes Martin Heidegger and Hans-Georg Gadamer, all of whom have discussed the concepts of Dasein and Umwelt to different extent, with Gadamer explicitly evoking Uexküll in his masterpiece. ${ }^{4}$ In the pages that follow, I will

4 For Husserl's discussion of Umwelt and Vorstellung, see, for instance, his 1934 essay, "Foundational Investigations of the Phenomenological Origin of the Spatiality of Nature" (Husserl 1982: 222-234). Here Umwelt is defined as "the surrounding world" (222). Heidegger devotes lengthy discussion to Umwelt in his Being and Time (Sein und Zeit 1927) (1963: 66ff, English, 1962: 93ff). According to him, "That world of everyday Dasein which is closest to it, is the environment" (94). ("Die nächste Welt des alltäglichen Daseins is die Umwelt" (66).) For Husserl and Heidegger, the prefix of um suggests both "around", as in Umsicht, and the more "intentional" preposition "for" as in Umgang. The two philosophers used the world Umwelt probably after Uexküll, and each with a Gegenentwurf, i.e., shifting the focus from animal world to human world. Kluge: Etymologisches Wörterbuch der deutschen Sprache (2002: 24) gives the word's 19th-century Danish origin, but identifies its conceptualization by Uexküll in 1909.

In Gadamer's Truth and Method the author alludes to Jakob von Uexküll and praises his alternative attitude to scientific study (Gadamer 1994: 451; 1986: 455): "[...] Thus, for example, the environmental studies (die Umweltforschung) of the biologist von Uexküll contrasted the world of physics to a universe of life composed of the manifold living worlds of plants, animals, and men. Such biological inquiry claims to overcome the naïve anthropocentricity of the earlier study of animals by investigating the particular structures of the habitats (Baupläne der Umwelten) in which living things have their being. Like animal environments (Umwelten) the human world is built of elements that are available to human senses (menschlichen Sinnen). If 'worlds' are to be thought of as biological plans, however, this not only assumes the existence of the world of being-in-itself that is made available through physics, in that one is working out the selective principles according to which the various creatures construct their worlds out of material that "exists in itself"; it also derives the biological universe 
briefly discuss Frege's and Husserl's use of Sinn, Bedeutung, and Zeichen to see how such concepts may have either informed or crisscrossed with Uexküll's theory of "meaning" and "sign."

According to Kalevi Kull's bibliography (Kull 2001: 16), Uexküll's first essays were published in $1892 .^{5}$ The same year saw the publication of Frege's article on Sinn and Bedeutung in Zeitschrift für Philosophie und philosophische Kritik, and in the previous year, 1891, Frege and Husserl had had correspondence on the semantic issue involving common name or concept word, with particular reference to the terms that concern us here (Frege, "Letter to Husserl, 24.5, 1891," in Frege 1997: 149-150). Most critics have suggested that Husserl's use of similar concept was under Frege's influence, though recent discoveries show that Husserl might have borrowed such terms from other sources. Very probably both Frege and Husserl had drawn upon identical materials, including contemporary logic, and were under the general influence of Kant. In 1890 Husserl published an article entitled "On the Logic of Signs (Semiotic)" ["Zur Logik der Zeichen (Semiotik)"]. The article is of historical importance. For one thing, it might have given birth to an alternative but aborted tradition of semiotics. For another, it anticipated Uexküll's concept of signs. A rereading of Husserl on sign may put Uexküll in a different perspective from semiotics.

It would be interesting to compare the three philosophers' theories of meaning and sign. Incidentally, the title of one of Uexküll's major writings, Bedeutungslehre, can mean both "theory of meaning" in general and "semantics" in particular. For all the profusion of signs throughout his work, Uexküll's contribution to theoretical biology has much to do with his theory of meaning. In fact, it would be negligent not to presuppose some kind of discursive rapport between Uexküll and Frege and Husserl regarding their discussions of meaning. The relationship of the three thinkers can be represented as an inverted

from the physical universe by a kind of restyling, and it indirectly assumes the existence of the latter. Certainly this constitutes a new kind of inquiry. It is a line of research generally known today as behavioral biology. Logically it would embrace the human species as well." In order to fully appreciate Gadamer's representation of Uexküll and his approach to biology, one needs to situate the statement in the larger context of philosophical hermeneutics.

5 Thure von Uexküll (1980: 403) identifies the two 1892 essays in Zeitschrift für Biologie 28 as 1891. 
pyramid (Fig. 1). Chronologically, Uexküll appears later on the vertex of this inverted triangle, the other two angles being occupied by the Husserl of "On the Logic of Signs (Semiotic)" dated 1890 (Husserliana 12: 340-373), and the Frege of "On Sinn and Bedeutung" dated 1892 (Zeitschrift fur Philosophie und philosophische Kritik 100: 2550). Both work anticipated Uexküll's discussions of meaning and sign, dating from 1909.

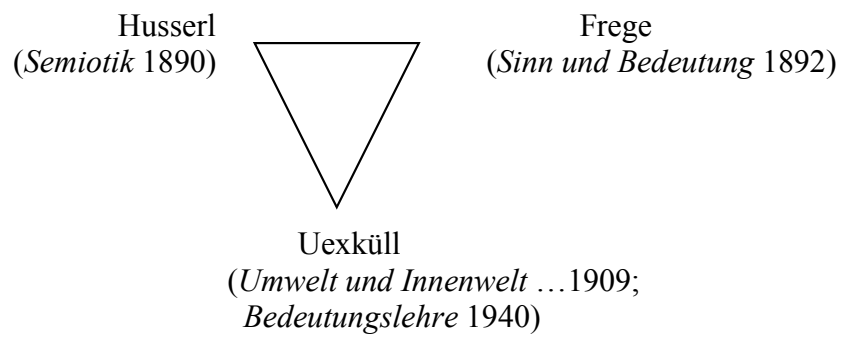

Figure 1. Uexküll, Frege, and Husserl.

In the following I will briefly negotiate the Uexküllian theory of Bedeutung, the Fregean distinction of Sinn and Bedeutung, and the Husserlian concept of noematic Sinn. My purpose is to show how Uexküll's use of terms, including the ubiquitous Zeichen, is very much concerned with the interpreted sense of hermeneutics. This applies to his interpretation of living organisms as well as his textual hermeneutics. For the latter, I will analyse one relatively obscure text which is a parody of Plato's dialogue The Meno, co-authored by Jakob and Thure, and by so doing attempt to show another unknown Uexküll as a hermeneutician of classics.

But let me begin with Frege. The theoretical implication of Frege in modern semiotics is yet to be explored, although his legacy on analytical philosophy cannot be denied. Semioticians in general have avoided him probably because of the bias that semiotics and logic are incompatible. Whereas logic is concerned with truth and the procedure of its acquisition, semiotics is interested in exploring an "alternative" truth, not confined to referentiality. Even Peirce, who equates logic to semeiotic, asserts abduction as a privileged semiotic reasoning rather than induction and deduction. 
In his seminal essay on Sinn and Bedeutung, Frege begins by talking about equivalence as represented by algebraic equation. Following Kant, he argues that $a=a$ is tautological or "analytic," and $a=b$ is more complicated and tricky than it appears. The latter gives rise to the thorny issue of name and reference, concept and object, or in semiotic parlance, signans and signatum, signifiant and signifié. In the first analytic equation, $a$ and $b$ as names are not equal but they can be made so because of their identical extension. Furthermore, if the extensions of two terms are identical, then there is no reason why the equation cannot be reversed to suggest that $a$ and $b$ as names are also equivalent. Therefore, in the purely nominal sense, there is an aporia in $a=b$ and $a \neq b$.

Take Frege's own example. The morning star (Morgenstern) refers to the planet Venus and the evening star (Abendstern) to the same planet. Now one could say that their references are identical, but the reverse is not true because the morning star $\neq$ the evening star. From the point of view of logical semantics, the two Zeichen, each with its Sinn, share one Bedeutung. A naïve conflation of semantics with semiotics would take the morning star as signifiant 1, and the evening star as signifiant 2, and the two signifiants share one signifié. But from the semiotic point of view, the morning star as Zeichen or sign already consists of an inseparable pair signifiant / signifié, the sensible and the intelligible. Put in Saussurian terms, the acoustic picture, i.e., the signifiant [abnt $[\mathrm{t} \partial \mathrm{rn}$ ] points to its semantic content of $\{$ Abendstern $\}$, or signifié. Let us see how Frege defines the relationship of expression and content in his famous puzzle.

It is natural, now, to think of there being connected with a sign (name, combination of words, written mark), besides that which the sign designates, which may be called the Bedeutung of the sign, also what I should like to call the Sinn of the sign, wherein the mode of presentation is contained. (Frege 1960: 152)

(Es liegt nun nahe, mit einem Zeichen [Namen, Wortverbindung, Schriftzeichen] ausser dem Bezeichneten, was die Bedeutung [des Zeichens heissen möge, noch das verbunden zu denken, was ich den Sinn des Zeichens nennen möchte, worin die Art des Gegebenseins enthalten ist.]) (Frege 1892: 27)

Frege here seems to be suggesting a triad consisting of Zeichen, Sinn, and Bedeutung. But in fact, the Bedeutung is exterior to the Zeichen rather than interior of it, especially when it stands for a referent or object, whether be the Zeichen a proper noun or a common noun. 
There is no such intrinsic semiotic relationship as among the Saussurian signifiant and signifie or the Peircian representamen, object, and interpretant. But does Frege grant motivation to the relationship between Zeichen and Sinn and Bedeutung? It is not surprising that he doesn't. Instead, he argues that the relationship between Zeichen and Bedeutung is arbitrary, and as such one cannot reverse Bedeutung to Zeichen because of the interference of mode of presentation (Art des Gegebenseins) contained in the Sinn (Frege 1960: 152). Moreover, a Sinn may not point to a Bedeutung, insofar as the latter means a referent (ibid.153). Here Frege anticipates Saussure's famous argument of the arbitrariness of the sign.

Frege has been much acclaimed by members of literary community because of his assertion that the Sinne of morning star and evening star are different, despite their shared Bedeutung. The poet, for one, is especially pleased for the license which enables her to relate the Fregean Sinn to the affective function of language expression. The same may not yet be true with the semiotician, as I have tried to demonstrate above, before she can clarify satisfactorily the conflation of semiotics and semantics in a statement as follows.

The regular connection between a sign, its Sinn and its Bedeutung is of such a kind that to the sign there corresponds a definite Sinn and to that in turn a definite Bedeutung, while to a given Bedeutung (an object [einem Gegenstande]) there does not belong only a single sign. The same Sinn has different expressions in different languages or even in the same language. (Frege 1892)

The difficulty of the passage, especially the latter part, lies in linguistic and semiotic trespassing. Because of system-specificity, no identical Sinn can be shared by different expressions in different languages, nor can a Bedeutung as object subsume more than one sign.

We can agree with Frege on the following. Every word, phrase, proposition has a sense (Sinn) and its meaning and/or reference (Bedeutung). In the case of proper noun, such as Angela, it has a sense whether etymological or otherwise. We all know Angela is a female angel, but normally Angela also refers to an individual person. The person referred to is the word's reference or referent and therefore its object. In this case Bedeutung refers to designation (Bezeichnung) rather than meaning. In the case of a common noun or in Frege's words, "concept word," the word has both a sense and reference 
(referent) but it does not have an object. Two kinds of relationships are involved here, one is subordination, and the other is subsumption. Since the verbal semantic of a word, namely Sinn, may lead to a concept and/or an object, one needs to discuss the intensional and extensional qualities of the concept and/or object. These relationships can be illustrated by Frege's diagram in his letter to Husserl in 1891 (Frege 1997: 149) (Fig. 2).

\begin{tabular}{|c|c|c|c|}
\hline proposition & proper name & concept word [common name & \\
\hline$\downarrow$ & $\downarrow$ & $\downarrow$ & \\
\hline Sinn & Sinn & Sinn & \\
\hline of the & of the & of the & \\
\hline proposition & proper name & concept word & \\
\hline \multicolumn{4}{|c|}{ (thought) [Gedanken] } \\
\hline$\downarrow$ & $\downarrow$ & $\downarrow$ & \\
\hline Bedeutung & Bedeutung & Bedeutung & object [Gegenstand] \\
\hline of the & of the & of the & falling under \\
\hline proposition & proper name & concept word & $\longrightarrow$ the concept \\
\hline (truth value) & (object) & (concept) & \\
\hline
\end{tabular}

Figure 2. Sinn and Bedeutung in Frege's diagram — in his letter to Husserl in 1891 (Frege 1997: 149).

We can see from the diagram that the heart of the puzzle lies in the possible confusion of object and concept, both being represented by the ambivalent Bedeutung. Whereas the proper name "Angela" stands for the woman bearing that name despite its Sinn, a common name is seen by Frege as a concept word and stands for a concept rather than an object. I think Frege's answer to Husserl is crucial to our understanding of Uexküll, as I will argue later.

About the same time when Frege coined the distinction, other people were talking about similar concepts in similar terms. Husserl, for one, used these terms in his early writings on arithmetic and logic, and later on his analysis of human experience in the world. To Husserl there is little distinction between Sinn and Bedeutung, and he had used them interchangeably. ${ }^{6}$ It is in the 1913 book Ideas that he proposes a

Although Husserl uses both words, he does distinguish Sinn and Bedeutung, holding the one to be sensory and the other mental and conceptual. Later he 
distinction: Bedeutung refers to meaning at the conceptual level, and "more particularly in the complex speech-form 'logical' or 'expressing' meaning" while Sinn, in its more embracing breadth of application, refers to sense or "meaning simpliciter" (Husserl 1931 [reprint 2002: 346]). Husserl's concept of language is more complicated because of its involvement with human psychical experiences and intersubjectivity. Before talking about Husserl's concepts of noematic Sinn and content in relation to Uexküll, I will first allude to his 1890 essay on "semiotik".

Very little about the semantic distinction is discussed here except that while Sinn represents the sensual aspect of expression, Bedeutung its conceptual aspect. When discussing the composite or indirect signs, Husserl does distinguish bedeutet from bezeichnet: "In the case of indirect signs it is necessary to distinguish: that which the sign signifies (bedeutet) and that which it denotes (bezeichnet). With direct signs the two coincide" (Husserl 2002: 23). In his later writings, however, Husserl retains only the pair of bedeuten /Bedeutung and extends Sinn to the totality of the noematic experience (Derrida 1982: 162 ; see footnote 6 ).

We restrict our glance exclusively to "meaning" (Bedeutung), and "meaning something" (Bedeuten). Originally these words relate only to the sphere of speech, that of "expression." But it is almost inevitable, and at the same time an important step for knowledge, to extend the meaning of these words, and to modify them suitably so that they may be applied in a certain way to the whole noetico-noematic sphere, to all acts, therefore, whether these are interwoven with expressive acts or not. With this in view we ourselves, when referring to any intentional experiences, have spoken all along of "Sinn" (sense), a word which is generally used as an equivalent for "Bedeutung" (meaning). We propose in the interests of distinctness to favour the word Bedeutung (meaning at the conceptual level) when referring to the old concepts, and more particularly in the complex speech-form "logical" or "expressing" meaning. We use the word Sinn (Sense or Meaning simpliciter) in future, as before, in its more embracing breadth of application. (Husserl 1931 [reprint 2002: 346])

observes: "Let us start from the familiar distinction between the sensory, the so to speak bodily aspect of expression, and its non-sensory 'mental' aspect. There is no need for us to enter more closely into the discussion of the first aspect, nor upon the way of uniting the two aspects [...]". 
As can be seen from the last quotation, the writer's main concern in the "Semiotik" essay is the nature and function of sign. According to Husserl, a Zeichen (that is, a symbolic or inauthentic sign) can represent an object (Objekt or Gegenstand) by virtue of a Merkmal, which is an intensional property, a distinguishing mark, a characteristic of the object, and is itself a sign, as the author terms it, a Merkzeichen. (Husserl 1994: 20-21; 1970: 30-341). The idea of marking or noticing suggests the sign user's conscious act upon an intended object, wherein lies the quality that catches his attention. Even here one already notices Husserl's emphasis on the role of the perceiving subject - a theme which he develops in his subsequent works and which is congenial to Uexküll's concept of animal's attitude towards its environment, albeit with a qualitative and species leap! But at the same time, Husserl believes that the characteristic which identifies an object for the perceiving subject and hence the sign that represents it is intrinsic to the object. This eclectic stance compromises his sign theory and makes it essentially transitive. One may recall in the opening of the essay his false distinction between authentic concept that does not need the mediation of signs and the inauthentic concept which can be represented only by signs.

Husserl provides a typology of signs to represent inauthentic concepts. It consists of half dozen pairs: (1) Extrinsic versus conceptual signs, where the former is what Frege means by proper noun, such as the name, and the latter is noted for its distinguishing Merkmal; (2) univocal versus multivocal signs, an instance of the latter being the general name for a concept; (3) simple versus composite signs; (4) direct versus indirect signs; (5) identical versus non-identical, or equivalent versus non-equivalent signs; (6) conventional versus natural signs; (7) formal versus material signs; (8) natural versus artificial signs. With minor revision, some of these categories actually address the Fregean distinction between proper name and common name. More importantly, they point to a common feature by virtue of which something can stand for, in Husserl's word, "deputize" or act as "surrogate" something else (aliquid stat pro aliquo). What is it? Husserl believes there is homogeneity between sign and object in that they share identical property and/or the sign may give rise to psychical processes or activities leading to this 
property. ${ }^{7}$ The concept that sign and what it denotes or designates are homogeneous is a popular concept in traditional semiotics. Likewise, few of us would deny that the observer and the observed are homogeneous.

Husserl's analysis of Zeichen, which he refers especially to symbolism in logic, includes no doubt language, and he believes that the linguistic sign as an instrument of inference carries corresponding psychical and symbolic aspects (Husserl 2002: 43). As an inauthentic, conventional, deputizing and surrogate sign system, language has only a secondary and subservient role to play, namely, "to serve as marks for remembering, as sensuous supports for psychical activities, as instruments of communication and conversation, and the like" (ibid. 44). Although he concedes that "[b]y far the largest part of symbolic representations and judgment processes rests upon language," nonetheless he observes that "linguistic signs quite certainly were not invented for this purpose, but rather to enable people to interact with one another" (ibid. 45). Obviously, Husserl, like Uexküll, is not interested in language, but how does he talk about meaning?

The Husserlian equivocation of Zeichen and Merkmal parallels Uexküll's later usage in his description of functional circle. He uses Sinn as two terms freely and interchangeably. Unlike Sinn in Frege, where it stands for meaning and only implicitly thought (Danken), for Husserl, Sinn is both a linguistic and perceptual entity, whose point of departure and return is human subjectivity. We use language to intend an object. This intentional use of language involves an act and its sense is what Husserl terms "noematic Sinn," and the object intended by this consciously linguistic act is Objekt (intentional object) or

In virtue of the fact that the deputizing signs (changing from moment to moment in relation to the same fact) either include in themselves, as a partial content, precisely the property upon which the momentary interest bears, or at least possess the aptitude to serve as the beginning or connecting point for psychical processes or activities which would lead to this property - or even to the full concept involved - and which we can arouse and produce wherever it may be required. If, for example, we are concerned with the concept of a sphere, then, like a flash, there appears with the word the representation of a ball, in which the shape along is specifically attended to. This accompanying representation, whose property crudely approximates to the intended concept and thereby symbolizes it, may then disappear once again, leaving only the word remaining. But its appearance nonetheless suffices in order to secure us in a confident grasp of the subject involved. (Husserl 2002: 31-32) 
Gegenstand which actually refers to "objective meaning". The phenomenological problem how to move from the immanent of consciousness to the transcendent external world can be solved, suggests Husserl, by an analysis how an object comes to have meaning for consciousness, and how consciousness relates to the object. This procedure is called intentional analysis, or the analysis of the constitution of meaning.

There is continuity between the subjective consciousness, its use of language on the object in external world, one could say. Compared with Frege, who is interested in logic's semantic procedure, Husserl is interested in the human subject's experience in and relationship to the world in which he lives. This kind of relation of "consciousness to an objectivity" is a phenomenological problem, and the problem has its "noematic aspect". Husserl asserts, "The noema in itself has an objective relation, through its own proper "meaning"" (Husserl 2002: 360 ). The double nature of noema, with a nucleus and changing characters, enables the "meaning" of consciousness to transmit itself to the "object", that is, its own object, whilst remaining the same (Husserl 2002: 360). In short, every noema has a "'content,' namely, its 'meaning' (Sinn) and is related through it to 'its' object" (Gegenstand) (Husserl 2002: 361).

This kind of analysis of noematic Sinn (i.e., meaning-component of an act), of highlighting the act of meaning-giving, of attributing sense to an object, is what Paul Ricoeur identifies as the subjective paradigm of knowledge, traceable to Dilthey but without the latter's scientistic pretension for objectivity. Whereas in Ricoeur's historiography, the two procedures of understanding and explanation are curiously identified with hermeneutics and semiotics (1990), Uexküll does not separate understanding and explanation, but his interpretive project in terms of sign, Husserlian or otherwise, shows his attempt at blurring the distinction, and maybe that of Naturwissenschaften and Geisteswissenschften. Ricoeur, though apparently not aware of Uexküll, may find it difficult to attribute Uexküll to either category. The biologist's project may be attributed to the category of explanation in his assumption that all animal perception and action in relation to the external world can be explained in terms of the operational procedure of sign processing. But at the same time, this Husserlian interest in Erlebnis, though of animal kingdom, including us homo sapiens and homo signans, and the teleological nature of his 
Bauplan, not short of reminiscence of the Kantian purposiveness of nature (Zweck, Zweckmässig) (Kant 2000: 71), is hermeneutical and phenomenological.

I am aware this is not the occasion to rehearse Uexküll on sign. Some carping formalists may find his semiotics failing to provide a rigorous theoretical model, an analytical tool as discovery procedure, despite the fact that the functional circle is self-explanatory. It works perfectly well as a top-down hermeneutic perceptual model whilst short of bottom-up analytical instrumentality. Furthermore, his concepts of sign and meaning are elusive and vague. For this reason, he is sometimes criticized for being anthropocentric, in other words, of treating animals as human subjects. I would say it is here that Uexküll sees eye to eye with Husserl although one is concerned with animals, the other with human beings.

Uexküll can be said to have followed Husserl in affirming the subjective paradigm, e.g., living organisms' intentional act on the objects of their environment. However, he does not care much about the Husserlian noematic Sinn, and less the Fregean verbal Sinn, but takes a cue from Kant and Johannes Müller to refer Sinn to the immediately sensational aspect, on both the physiological and psychological levels. As with Husserl, there is continuity between this sensational Sinn and the intended object. The articulation of this physio-psychological sense in language, i.e., linguistic Sinn and its transposition onto animals, is what he calls Bedeutung, as in "Bedeutung des Gegenstandes" (1928: 86). Incidentally, the word came to be used rather late: the index to the second edition of Theoretische Biologie (1928) shows that the word Bedeutung is used only once (twice on the same page), compared with Zeichen for seven times, Sinneszeichen for eight times, and other Sinnes- prefixed words for forty times.

One critic has pointed out the close relationship between the Husserlian concept of intentionality via noematic Sinn and the Fregean concept of Bedeutung via Sinn. (McTintyre: 220). One may wish to extend this analogy by relating the Uexküllian Bedeutung to the Husserlian noematic Sinn, but before the Husserlian Sinn, there is the purely sensational, instinctual, and non-lingual Uexküllian Sinn. This transference from the sensational Sinn to the intended object constitutes the Bedeutung of Umwelt. Take a well-known example. The tick waiting for its mammalian prey (food-function), not 
"knowing" exactly what will appear next illustrates the Hursselian/ Uexküllian "act"'s non-specific "phenomenological content". Further analysis of Uexküll's cognitive and pragmatic universe in terms of the Husserlian Merkmal, Zeichen, content-qualities, horizon, etc., and the Heideggerian hermeneutic circle is beyond the scope of this paper, but will be provided in a sequel on another occasion. Now let me turn to the Platonic parody.

\section{A biological parody: Uexküll as textual hermeneutician}

Jakob von Uexküll annotates the title of his adaptation of Plato's Meno in a footnote which reads as follows:

The reinterpretation of Nature by biology, which will prevail in spite of all obstacles, has brought our thinking closer to antiquity, giving us the chance to reinvigorate our perused terminology with the help of the resources to be found in the thoughts of the greatest minds of mankind. The way to Plato thus being cleared, I perceived the idea to seek enlightenment on pressing biological questions from the great Sage. As means to this end, I chose to make Socrates continue one of his dialogues, with the adjustment of giving him the knowledge of our contemporary biological problems. Thus some kind of interaction between the Ancients and ourselves is created, to our considerable benefit. (Uexküll, Uexküll 1943: 126) ${ }^{8}$

This apologia pro sua has profound implications for anyone familiar with the hermeneutic tradition of textual interpretation. There is no need to reiterate the commonplace that translation, following explanation, is an integral part of textual hermeneutics. And in the modern tradition of philosophical hermeneutics since Heidegger - rather than Schleiermacher, the fusion of horizons has become a trendy notion, a critical term, that is, first articulated by Husserl but later refined by Gadamer and put to use in literary criticism by Hans Robert Jauss of the next generation.

Jakob von Uexküll's interest in recontextualising classical texts is seen on many occasions. A more familiar case is the motto with which he prefaces the famous Bedeutungslehre booklet. The English translation has for mysterious reasons deleted the word "Motto" and the source: "Übersetzt von Karl Kindt, Platon Brevier. Karl Rauch

8 The translation was done by Edgar Vögel. 
Verlag." Maybe Professor Sebeok, as hermeneutician supervising the translation, did not find the information important for semioticians, but I believe it is indispensable to any serious Uexküll scholar, not only one who is interested in archaeology, and for that matter, a Uexküllian archive, but also for someone trying to establish Uexküll as a rhetorician and polemist. Before returning to the Meno variation, let me essay an exegesis of the Motto and the dramatic scene the writer sets for his audience and himself.

The Motto is taken from Plato's late dialogue The Sophist which deals, among other things, with the problematic of representing truth, both by language and visual art. In a recent paper, I have discussed the issue of iconicity in the dialogue in relation to Peirce (Chang 2003). In a strong sense, the dialogue is a debate over the pros and cons of iconic sign, but this is not the occasion to rehearse it. The Motto Uexküll quotes is a transition in the dialogue at which point conversation alludes to the myth of the Battle of Giants, which actually is a burlesque of the debate on the ontology of the universe by two camps of natural philosophers, the materialists and the idealists. It should be clear now why Uexküll uses this ancient fable inserted into the dialogue of The Sophist as his Motto. There is an analogy between the ancient fabulous debate and the current debate between the vitalists and mechanists. I am not saying Uexküll is a member of either camp, or for that matter, of any one of the four camps, past and present. But one should not fail to notice this dialogic answerability dear to Gadamer.

The interesting thing about the Motto is what immediately follows, that is, Uexküll's dramatic point of attack that opens his discourse on meaning. His discourse opens as a Socratic defense, familiar to anyone who has read the early dialogues of Plato, simply called the Socratic Dialogues, after the protagonist, especially The Apology, Crito, and Phaedo. Jakob's (or in literature we would say his persona's) stance is exactly like that of Socrates who is accused of corrupting Athenian youths by preaching falsehood. I know very little German, but my informants, including a native German-speaking professor of linguistics originally from Humboldt University, have told me the stylistic difference in the original German version and the white-washed English translation. Why Jakob displays this kind of archaic martyr complex when summoned to the law court is beyond my comprehension and I believe any of my biologist colleagues is 
more competent than myself to hazard an answer. Given the tone, said much harsher in German, there is no denying that Uexküll is a fellowtraveller of ancient rhetors, and in this case, a Socrates-surrogate.

Now back to the "Eternal Question" dialogue. Jakob puts it modestly in the footnote cited above that he has put biology into Socrates' mouth. In the sense of disciplinary history, his observation is accurate, but there is no accident in this world of causality. Let me make and take another excursion. We all know Aristotle is a forerunner of life science, but nothing significant can be said about Plato and still less about Socrates. Let me prove that the historian is wrong.

According to Erik Nordenskiöld - a source for Cassirer, "Nature did not interest him [Socrates] in least; the streets of Athens were his haunt, he said, and neither trees nor stones had anything to teach him" (1935: 31). I think the author simply had not read enough — his ignorance of Chinese botanical science long before Linnaeus' classification is another example. I suspect that Jakob's letting Socrates discuss biology is not groundless. This parody by the Uexküll's is also prefaced by a Motto, taken not from The Meno, the dialogue to be parodied, but from The Phaedo. I am afraid that not many people know that it is in this farewell dialogue that Socrates makes a confession, not to committing crime of seduction, but to giving up biology in youth. Shortly before his drinking the poison, Socrates tells Cebes:

When I was young, Cebes, I had an extraordinary passion for that branch of learning which is called natural science. I thought it would be marvelous to know the causes for which each thing comes and ceases and continues to be. I was constantly veering to and fro, puzzling primarily over this sort of question. Is it when heat and cold produce fermentation, as some have said, that living creatures are bred? Is it with the blood that we think, or with the air or the fire that is in us? Or is it none of these, but the brain that supplies our senses of hearing and sight and smell, and from these that memory and opinion arise, and from memory and opinion, when established, that knowledge comes? Then again I would consider how these faculties are lost, and study celestial and terrestrial phenomena, until at last I came to the conclusion that I was uniquely unfitted for this form of inquiry. (Plato, Phaedo 96a-c)

Socrates admits to being unable to study natural science, including life science, because, among other things, he cannot solve the mystery of origin, growth (96d) and causality (97d). Out of this Darwinian 
frustration, he turned from "natural philosophy" to philosophy proper and eventually cost his life.

With this, we turn to the Uexküllian biological variations. The topic that launches the debate in The Meno is the Greek virtue of arete or excellence in worldly affairs, but, as I have argued elsewhere, Socrates' main concern is the paradox of learning in life (Chang 2002). Socrates' interlocutor is Meno, follower of the famous sophist Gorgias. In the course of refuting Meno with his famous strategy of elenchos, Socrates turns to a slave boy of Meno's, engaging him to a series of Q\&A. Socrates uses geometry to test the slave boy's immanent intelligence, and succeeds in demonstrating that human intelligence is an in-born ability of inference, and it cannot be taught. Now it is immediately at this turning point to the original Platonic dénouement that Uexküll inserts biology to prolong the torture of that hapless slave boy. Characteristically, Uexküll again makes a qualitative species jump, this time from human immanent intelligence to animal instinct, as he is to develop in the space that follows. This echoes his shift, in theoretical writings, from Husserlian human consciousness to animal cognition, both to him being immanent.

Our hermeneutic exegesis is not completed yet. There remains one final question on that eternal question of life: Why does Uexküll insert biology after geometry? The answer cannot be easier. Why? He is a biologist! But again we need to situate the question in Western disciplinary history. One recalls that Kant in Critique of the Power of Judgment opens his "Analytic of the Teleological Power of Judgment" (5: 362, Kant 2000: 235) by geometry, and he praises Plato for the Greek philosopher's knowledge of geometry (Ibid., 236). According to Cassirer, in Die Lebenslehre Uexküll juxtaposes geometry and biology. Since I have not been able to locate the original, let me quote indirectly from Cassirer:

The real analogue to the concept of biological form is not to be found in the world of material things or processes with which physics is concerned, but must be sought elsewhere, in the pure relationships of geometry and stereometry.

Structure is not a material thing: it is the unity of immaterial relationships among the parts of an animal body. Just as plane geometry is the science not of the material triangles drawn on a blackboard with chalk but of the immaterial relationships between the three angles and three sides of material parts united in a body so as to reconstitute the structure in imagination. (Uexküll 1930: 9) 
Cassirer adds, "With that view the program of "idealistic morphology" [proposed by Goethe] was being thoroughly resurrected" (Cassirer 1950: 200).

\section{References}

Burghardt, Gordon M. (ed.) 1985. Foundations of Comparative Ethology. (Mellor, Chauncey J.; Grove, Doris, trans.) New York: Van Nostrand Reinhold.

Cassirer, Ernst 1950. The Problem of Knowledge: Philosophy, Science, and History since Hegel. Trans. Woglom, William H.; Hendel, Charles W. New Haven: Yale UP.

Chebanov, Sergey V. 1993. Biology and humanitarian culture: the problem of interpretation in bio-hermeneutics and in the hermeneutics of biology. In: Kull, Kalevi; Tiivel, Toomas (eds.), Lectures in Theoretical Biology 2. Tallinn: Estonias Academy of Sciences, 219-248.

Chang, Han-liang 2002. Paradox and the elenchus in Plato's Meno, Augustine's De Magistro, and Gongsun Long's Jianbai lun (Discourse on hardness and whiteness). Paper presented at International Conference on Argumentation in Dialogic Interaction, Lugano, Switzerland, 30 June-3 July 2002.

- 2003. Plato and Peirce on likeness and semblance. Paper presented at the 4th Conference on Iconicity in Language and Literature, Université catholique de Louvain, Louvain, Belgium, 27-29 March 2003.

Derrida, Jacques 1982. Margins of Philosophy. Trans. Bass, Alan. Chicago: University of Chicago Press.

Dreyfus, Herbert (ed.) 1982. Husserl, Intentionality, and Cognitive Science. Cambridge: MIT Press.

- 1982. Husserl's perceptual noema. In: Dreyfus, Hubert L. (ed.), Husserl Intentionality and Cognitive Science. Cambridge, Mass.: The MIT P, 97-123.

Frege, Gottlob 1892. Über Sinn und Bedeutung. Zeitschrift für Philosophie und philosophische Kritik 100: 25-50.

- 1960. Transactions from the Philosophical Writings of Gottlob Frege. Geach, Peter; Black, Max (eds.). Oxford: Blackwell.

- 1997. The Frege Reader. Beaney, Michael (ed.). Oxford: Blackwell.

Gadamer, Hans-Georg 1986. Wahrheit und Methode. Ergänzungen Register. Tübingen: J.C.B. Mohr (Paul Siebeck). 2 Banden. Band 1.

- 1994. Truth and Method. 2nd rev. ed. Trans. Weinsheimer, Joel; Marshall, Donald G. New York: Continuum.

Heidegger, Martin 1962. Being and Time. Trans. [from the 7th ed.] Macquarrie, John and Edward Robinson. New York: Harper \& Row.

- 1963. Sein und Zeit. Zehnte, unveränderte Auflage. Tubingen: Max Niemeyer.

Husserl, Edmund 1950. Ideen zu Einer Reinen Phänomenologie und phänomenologischen Philosophie. (Husserliana: Edumund Husserl Gesammelte Werke. Band III.) Haag: Martinus Nijhoff. 
- 1970. Logical Investigations. (Findlay, J. N., trans.) New York: Humanities Press.

- 1970. Philosophie der Arithmetik: Mit Ergänzenden Texten (1890-1901). In: Eley, Lothar (ed.), Husserliana: Edmund Husserl, Gesammelte Werke. 12 vols. Den Haag: Martinus Nijhoff. 12.

- 1994. On the logic of signs (semiotic). In: Trans. Willard, Dallas, Early Writings in the Philosophy of Logic and Mathematics. In: Bernet, Rudolf (ed.), Edmund Husserl: Collected Works. 5 vols. Dordrecht: Kluwer. 5: 20-51.

- 2002 [1931]. Ideas: General Introduction to Pure Phenomenology. (Gibson, W. R. Boyce, trans.) London: Routledge.

Kant, Immanuel 2000. Critique of the Power of Judgment. Guyer, Paul ed. Trans. Guyer, Paul; Mathews, Eric. Cambridge: Cambridge UP.

Kull, Kalevi 2000. Copy versus translate, meme versus sign: development of biological textuality. S: European Journal for Semiotic Studies 12(1): 101120.

- 2001. Jakob von Uexküll: An introduction. Semiotica 134(1/4): 1-59.

Laubichler, Manfred D 1997a. Some reflections on Wittgenstein and biology. S: European Journal for Semiotic Studies 9(2): 377-386.

- 1997b. The nature of biological concepts. S: European Journal for Semiotic Studies 9(2): 251-276.

McIntyre, Ronald 1982. Intending and referring. In: Dreyfus (ed.) 1982: 215-231.

Mohanty, J.N. 1982. Husserl and Frege: a new look at their relationship. In: Dreyfus (ed.) 1982: 43-52.

Nordenskiöld, Erik 1935. The History of Biology: A Survey. Trans. Eyre, Leonard Bucknall. New York: Tudor.

Ricoeur, Paul 1974. The Conflict of Interpretations. Evanston: Northwestern UP.

- 1990. Between hermeneutics and semiotics: in homage to Algirdas J. Greimas. International Journal for the Semiotics of Law 3(8): 115-132.

Uexküll, Jakob von 1909. Umwelt und Innenwelt der Tiere. Berlin: Verlag von Juilius Springer, 1909.

- 1930. Die Lebenslehre. Potsdam: Müller und Kiepenheuer Verlag.

- 1931. Die rolle des subjekts in der biologie. Die Naturwissenschaften 19(19): 385-391.

- 1940. Bedeutungslehre. Leipzig: Verlag von Johann Ambrosius Barth.

- 1947. Der Sinn des Lebens: Gedanken über die Aufgaben der Biologie mitgeteilt in einer Interpretation der zu Bonn 1824 gehaltenen Vorlesung des Johannes Müller Von dem Bedürfnis der Physiologie nach einer philosophischen Naturbetrachtung. Godesberg: Verlag Helmut Küpper.

- 1980. Kompositionslehre der Natur: Biologie als undogmatische Naturwissenschaft Ausgewählte Schriften. Herausgegeben, Uexküll, Thure von. Frankurt am Main: Verlag Ullstein GmbH.

- 1985. Excerpts from Environment [Umwelt] and Inner World of Animals. In: Burghardt (ed.) 1985: 222-245.

Uexküll, Jakob von; Uexküll, Thure von 1943. Die Ewige Frage: Biologische Variationen über einen platonischen Dialog. Europaische Revue 19(3): 126- 
147. English translation as "The eternal question: Biological variations on a Platonic dialogue", by Edgar Vögel (in this volume, p. 329-362).

- 1987. The sign theory of Jakob von Uexküll. In: Krampen, Martin; Oehler, Klaus; Posner, Roland; Uexküll, Thure von (eds.), Classics of Semiotics. New York: Plenum, 147-179.

Uexküll, Thure von; Wesiack, Wolfgang 1997. Scientific theory: a bio-psychosocial model. In: Uexküll, Thure von (ed.), Psychosomatic Medicine. Munchen: Urban \& Schwarzenberg, 11-42.

\section{Семиотик или герменевтик: Якоб фон Юкскюлл}

Подобно другим наукам, биосемиотика также имеет свой исторический архив, в котором содержатся работы основателей дисциплины. Одним из таких является Якоб фон Юкскюлл, которого называли первопроходцем семиотики, так как он, независимо от Соссюра и Пирса, развивал теорию знака и значения. Сопоставление 'знака' и 'значения' при этом весьма существенно, ведь получается, что с равным основанием можно Юкскюлла считать как семиотиком так и герменевтиком. Такой новый подход оправдывается продолжительным интересом Юкскюлла к понятиям 'смысл' (Sinn) и 'значение' (Bedeutung), начало которого отражено в одной из его первых книг в 1909 году. Данная статья пытается восстановить непосредственный интеллектуальный “исторический горизонт” Юкскюлла, то дискурсивное пространство, в котором находились его современники Гуссерль и Фреге. В частности, предполагается выяснить, как повлияли другие философы языка на размышления Юкскюлла над знаком (Zeichen) и объектом (Gegenstand), смыслом (Sinn) и значением (Bedeutung), и как Юкскюлл (в качестве феноменологического герменевтика) вписывается в традицию Гуссерля, Хейдеггера и Гадамера. Чтобы предотвратить возможную критику: мол, герменевтика занимается в основном текстовыми интерпретациями, в то время как Юкскюлл в лучшем случае интерпретирует жизнь животных, - в статье рассматривается неоконченная пародия Юкскюлла на диалог Платона "Менон” под названием Die ewige Frage: Biologische Variationen über einen platonischen Dialog (1943). Пример такой работы с текстом свидетельствует, что Юкскюлл одновременно является и адресатом, который занимается толкованием древних текстов, и адресантом, который записывает свои объяснения для следующей группы адресатов. Такой подход выступает за границы биологии, вступая в область риторики и лингвистической прагматики речевых актов. 


\section{Semiootik või hermeneutik? Jakob von Uexküll, taas}

Sarnaselt teiste teadustega on ka biosemiootikal oma ajalooline arhiiv, mis sisaldab distsipliini eelkäijatena avastatud ja austatud inimeste töid. Üheks selliseks on Jakob von Uexküll, keda on nimetatud semiootika teerajajaks, kuna ta arendas Saussure'ist ja Peirce'ist sõltumatult märgi ja tähenduse teooriat. 'Märgi' ja 'tähenduse' kõrvutamine seejuures on tähendusrikas, sest ühtviisi põhjendatult võib Uexkülli pidada nii semiootikuks kui hermeneutikuks. Taolist uudset seisukohta võib õigustada Uexkülli pikaajalise huviga mõistete 'tähendus' (Sinn) ja 'osutus' (Bedeutung) vastu, mis sai alguse tema ühest esimesest raamatust 1909. aastal. Käesolev artikkel püüab taastada Uexkülli vahetut intellektuaalset ajaloolist horisonti, diskursiivset ruumi, milles viibisid tema kaasaegsed Husserl ja Frege. Nii peaks selguma, kuidas olid Uexkülli arutlused, mille teemadeks märk (Zeichen) ja objekt (Gegenstand), tähendus (Sinn) ja osutus (Bedeutung), mõjutatud teistest keelefilosoofidest, ning kuidas asetub Uexküll fenomenoloogilise hermeneutikuna Husserli, Heideggeri ja Gadameri traditsiooni. Ennetamaks ja tõrjumaks võimalikku kriitikat, et hermeneutika tegeleb peamiselt tekstilise tõlgendusega, samas kui Uexküll on parimal juhul loomade elu tõlgendaja, käsitleb artikkel Uexkülli lõpetamata jäänud Platoni dialoogi Meno paroodiat pealkirjaga Die ewige Frage: Biologische Variationen über einen platonischen Dialog (1943). Niisugune tekstiga töötamine annab tunnistust Uexküllist, kes kehastab samaaegselt vanade tekstide mõistmisega tegelevat vastuvõtjat ning teist saatjat, kes paneb kirja oma selgitused veel ühele vastuvõtjate grupile. Selline tegevus ületab juba bioloogia piirid ning hõlmab retoorika ja kõneaktide lingvistilise pragmaatika. 